\title{
School Legislation of Ecumenical Councils from the 12th to the First Half of the 14th Century and the Beginning of its Reception in Medieval Poland - the Outline of the Problem
}

\begin{abstract}
The aim of the paper is an analysis of a broadly understood legislation of general councils which took place in an important period for the development of the then educational system and culture at the height of the Middle Ages (12th-13th c.). While analysing the written records of synodal and council acts, several interesting aspects can be considered: the regulations related to the education of clergy (the diocesan ones, as the same issues concerning monastic orders were regulated by the inner legislation of general chapters), the organization of schools and teaching programmes, the records telling about the moralizing influence on the community of the faithful, and finally, the attitude of the Church toward the question of general access to education, including the functioning of universities.

The presented study demonstrates a significant role of ecclesiastical school legislation for the development of the educational system in mediaeval Poland. Also, it can be noticed that all changes in this matter were the result of legislative activity of the Church but also responded to the educational needs of the contemporary society. The latter, in turn, stemmed from a general civilizational development of Latin Europe, the part of which were the lands being under the rule of the Piast dynasty.
\end{abstract}

Keywords: school legislation, Middle Ages, history of education

The medieval education system was dominated by the Church, and a significant number of litterati of that time wore clerical clothing. In general, the word clerk (a cleric) was the synonym for an educated man. This situation was at least until the end of the middle ages, and without risking a mistake it can be said that it maintained until the "school revolution" of the Reformation and Counter-Reformation. The reasons for this were numerous, and the process of taking over the education, which had had a secular character in Greek and Roman times, by the clergy - was extremely complicated and long-lasting. Suffice it to say that while the command of writing and reading comprehension was 
not something unusual in the late Christian Roman Empire, it was extremely rare among lay people in the Carolingian era. The consequence of the Church's extremely strong influence on various spheres of medieval life was also an almost complete monopoly in the field of education and (probably to a lesser extent) child-rearing. It was not until the twelfth and thirteenth centuries that far-reaching changes took place in this respect, which however did not mean demonopolisation, but only more widespread teaching and the covering lay people by it.

This paper is to analyse legislation (in its wider sense) of ecumenical councils held during the High Middle Ages, a period significant for the development of education and culture, namely the 12 th and early 13 th centuries. It was the time when universities emerged and were dynamically developing, the period of growing interest in school education also at the elementary level, but also the vast widening of intellectual horizons and cultural needs of the knighthood, middle class and probably also peasants. We should not, therefore, limit our analysis to records concerning stricte schools, but it is worth extending to a few important groups of subjects that reflect the then current social, economic and cultural transformations of medieval Christianitas, which was dominated in the West (and attempting also to take root in eastern Europe through the fourth Crusade) by Latinitas the community of the official language of the Church.

By analysing the provisions of synodal and conciliar laws, we can distinguish several aspects of our interest: provisions regarding education of the clergy (namely diocesan clergy, since for religious orders these issues were regulated by internal legislation of their respective general chapters), organization of schools and curricula, further provisions referring to preaching in general and, finally, the Church's attitude to the universality of teaching, including universities.

The period concerned was, within the Church, under the overwhelming influence of the four general councils held in Rome, Lateran, and implementing the programme of the reform initiated by Pope Gregory VII (1073-1085) and then a number of provincial synods ${ }^{1}$, while subsequent medieval councils (in Lyon and Vienne) were of less importance. Naturally, the attitude of church authorities to education was a product of the cultural situation at the time, but it also stemmed from a centuries-old tradition. This tradition was born in the 6th century, when a significant disintegration of the Roman school system took place, and simultaneous Christianisation successes and an increase in the number of parishes encouraged the creation of a new school system, mainly for the education of priests ${ }^{2}$.

\footnotetext{
1 MINNERATH, R., Sobory, Warsaw 2004, p. 58 et seq.
}

2 The evolution of the Church's approach to the issue of education in the first centuries of Christianity will be further analysed in more detail by the author in another text. Based on the files of synods and councils, I will point out here, only by way of example, that while in the fourth century the problem of lack of literacy acquired from school did not exist (see: Canon VII of the First Council of Constantinople of 381, [in:] Dokumenty soborów powszechnych, vol. 1: Nicea I, Konstantynopol I, Efez, Chalcedon, Konstantynopol II, Konstantynopol III, Nicea II, ed. A. BARON, H. PIETRAS SJ, Kraków 2001, p. 93 and the conclusion of the Synod of Elvira of ca. 306: "A woman may not write to other lay Christians without her husband's consent. A woman may not receive letters of friendship addressed to her only and not to her husband as well"-Synody i kolekcje praw, vol. 1: Dokumenty synodów od 50 do 381 roku, compiled by A. BARON, H. PIETRAS SJ, Kraków 2006, p. 61), while 
The problem was noticed as early as at the Synod of Arles (524): Tamen quia crescente ecclesiarum numero necesse est nobis plures clericos ordinare ${ }^{3}$. The establishment of church schools became a way to improve the education of candidates for the priesthood. During the Synod of Toledo, held in 527 under the presidency of Bishop Montanus, a decision was made to establish an episcopal school. Canon I of the synod regulated the functioning of the school as follows: De his quos voluntas parentum a primis infantiae annis clericatus officio emanciparit statuimus observandum ut mo cum detonsi vel ministerio lectorum contraditi fuerint in domo ecclesiae sub episcopali praesentia a praeposito sibi debeant eruditi. At ubi octavum decimarum aetatis suae complaverint annum coram totius cleri plebisque conspectu voluntas eorum de expetando conjugio ab episcopo perscrutetur ${ }^{4}$. As it can be seen, school was intended only for future clerics (an obligation to cut the tonsure), but the choice was offered to young people: after the age of 18, they could decide on their further life path: either secular life and marriage or church career. In 529, the Synod of Vaison decided that every priest of a village parish teach children basic prayers, holy texts and the law of God. The canon of this Synod is considered an act that gave rise to parish schools ${ }^{5}$. Finally, the Third Council of Toledo (589) developed the principles of the programme: the school education was to begin with learning the psalter, then the Holy Scriptures and hagiographic texts were studied. All these provisions were subsequently included in the council legislation of the thirteenth century, via the rules established during the Carolingian Renaissance, proclaiming the right of people of any social status to be educated $^{6}$. At that time, also the obligation to teach the faithful the rules of faith by properly

as soon as in the 5th century, in the church law emerges the issue of clergymen "undertaking care over minors"the Council of Chalcedon (451), Canon III, [in:] Dokumenty ..., vol. 1, p. 227.

${ }^{3}$ As cited in: RICHÉ, P., Edukacja i kultura w Europie Zachodniej (VI-VIII w.), Warsaw 1995, p. 109.

${ }^{4}$ Ibidem.

5 "Hoc enim placuit ut omnes presbyterii qui sunt in parochiis constituti secundum consuetudinem quam per totam Italiam satis salubriter teneri cognovimus juniores lectores quantoscumque sine uxoribus habuerint secundum in domo ubi ipsi habitare videntur rescipant, et eos quomodo boni partes spiritaliter nutrientes psalmos pavare divinis lectionibus insistere et in lege Domini erudiro contendant ut et sibi dignos successores provideant et a Domino praemia aeterna rescipiant." Ibidem, p. 139. It is worth noting the instruction that each teacher should prepare a successor. The decline of general education is becoming visible. Very often, the death of a teacher meant the termination of the school's operation. Not only was this a result of the general crisis of the Roman state and material deprivation and war damage but seemingly the noticeable lack of interest in education issues was an equally important factor.

${ }^{6}$ A great example of such church school rules are the resolutions of the Aachen Chapter after the synod of 822: "Scolas itaque, de quibus hactenus minus studiosi fuimus quam debueramus, omnio studiossime emendare cupimus, qualiter omnis homo sive maioris sive minoris aetatis, qui ad hoc nutritur, ut in aliquo gradu in ecclesia promoveatur, locum denominatum et magistrum congruum habeat. Parentes tamen vel domini singulorum de victu vel substantia corporali, unde subsistant providere studeant, qualiter ita solatium habeant, ut propter rerum inopiam a doctrinae studio non recedant" - Monumenta Germaniae Historica [hereinafter cited as: $M G H$ ], legum sectio III: Concilia, vol. 2: Concilia aevi Karolini I, pars 1, part 2, ed. A. WERMINGHOFF, HannoverLeipzig 1908, p. 471. 
educated preachers was introduced ${ }^{7}$. Bishops had to take care of appropriate staff ${ }^{8}$. A similar responsibility was entrusted to the superiors of monasteries ${ }^{9}$. Charlemagne also proclaimed: "that the psalms, the notes, the singing, the computation, the grammar be taught, and that books carefully corrected be in every bishopric and in every monastery" 10 . The King of the Franks, and the later Emperor, put forward the matter of the organization of education to provide the necessary basis for general education for the clergy. In the abovementioned text, known as Admonitio generalis dated 789, the future Emperor presented a school reform programme that would provide the subjects of the empire with a sense of belonging to one cultural community ${ }^{11}$. The Carolingian school legislation was included in the provisions of the Fourth Council of Constantinople (869-870) ${ }^{12}$. The results of the extensive education development programme did not meet Charlemagne's expectations, and subsequent centuries did not bring significant changes in this respect. This is understandable considering the general crisis of the Church, especially in the 10th century. The Church recovered from this crisis in the 11th century owing to, among others, Pope Gregory VII.

As mentioned before, the First Council of the Lateran was to continue the reforms of Pope Gregory VII (1073-1085). About 300 bishops and abbots took part in it, and the proceedings were held from 18 March to 6 April 1123. At that time, attention was paid to the need to increase religiousness among the faithful, and hence to the quality of teaching the truths of faith in churches ${ }^{13}$. More specific resolutions on school issues were taken during the Second Council of the Lateran held on 2-17 April 1139. It might seem strange but clerics were then forbidden to study secular subjects ${ }^{14}$. The conclusion is that such secular subjects as Roman law and medicine were recognized as the domain of the world of pro-

${ }^{7}$ Canones concilii romani (826), III, MGH, Concilia, vol. 2, p. 568.

${ }^{8}$ Cf. e.g.: Concilium parisiense (6 June 829), cap. XXX, [in:] Ibidem, p. 632.

9 It was an initiative of Charlemagne who during he Synod of Aachen in 802 mandavit, ut unusquisque episcopus in omni regno vel imperio suo, ipsi cum presbyteris suis, officium, sicut psallit ecclesia Romana, facerent. Nam et scholas suas cantorum in loca congrua construi praecepit. Similiter et in monasteriis sancti Benedicti servantibus regulam, ut offocium ipsius facerent, sicut regula docet, $M G H$, Concilia, vol. 2: Concilia aevi Karolini I, pars 1, ed. A. WERMINGHOFF, Hannover-Leipzig 1906, p. 230.

${ }^{10}$ Admonitio generalis, ed. A. BORETIUS, [in:] MGH, Capitularia regum Francorum, vol. 1, p. 54 et seq.; See also: RICHÉ, P., op.cit., p. 503. This order was issued in 789. Cf.: Karol Wielki, Warsaw 1959, p. 259 et seq.; FAŁKOWSKI, W., Admonitio generalis Karola Wielkiego-zapowiedź tworzenia państwa idealnego, [in:] Ludzie, Kościól, wierzenia. Studia z dziejów kultury i społeczeństwa Europy Środkowej (średniowiecze-wczesna epoka nowożytna), ed. W. IWAŃCZAK, S. K. KUCZYŃSKI, Warsaw 2001, p. 419-428.

11 The author is working on a separate study on school reforms of the Carolingian era.

12 Dokumenty soborów powszechnych, Greek, Latin, Polish texts, vol. 2: (869-1312) Konstantynopol IV, Lateran I, Lateran II, Lateran III, Lateran IV, Lyon I, Lyon II, Vienne, ed. A. BARON, H. PIETRAS SJ, Kraków 2002, Canons III and VII, p. 55-67.

13 See: Ibidem, p. 125 et seq.

${ }^{14}$ Ibidem, Canon IX: "[...]monks and canons regular, after receiving the habit and making their profession, are learning civil law and medicine with a view to temporal gain. [...]Therefore, we forbid by apostolic authority this practice to continue." 
fanum, and that lay people were acquiring knowledge in this field, though under the control of the Church.

Even more attention of the Council Fathers was focused on the matters of education during the Third Council of Lateran. The Council was convened by Pope Alexander III on 5 March 1179, after signing the peace with the Emperor Frederick Barbarossa in 1177. The deliberations by over 300 bishops and abbots, as well as representatives of military orders and numerous lay people, lasted from 5 to 22 March 1179. None of the Polish clergy participated $^{15}$, but this was not an obstacle for Polish bishops to learn about the contents of the Council's provisions.

Canon III thereof postulates that candidates for clergy are expected to get appropriate education, and this applies especially to bishops ${ }^{16}$. The Council established schools at cathedrals and major parish churches. Canon XVIII obliged the bishops to create them, "since the church of God is bound to provide like a mother for those in want, with regard to both the things which concern the support of the body and those which lead to the progress of the soul, therefore, in order that the opportunity of learning to read and progress in study is not withdrawn from poor children who cannot be helped by the support of their parents" 17 . This demonstrates that schools operated in large numbers, causing a specific drive to learn also among the poorer social strata, seeing education as a chance for their material and social advancement. Therefore, the Council decided that "in every cathedral church a master is to be assigned some proper benefice so that he may teach the clerics of that church and the poor scholars. In other churches and monasteries too, if anything in times past has been assigned in them for this purpose, it should be restored. Let no one demand any money for a licence to teach" ${ }^{\prime 18}$. This resolution ultimately sanctioned the expansion of parish education. It was also emphasized that "thus the needs of the teacher are to be supplied and the way to knowledge opened for learners ${ }^{19}$." The issue of the qualifications of those raising young children was also tackled. Canon 26 stated that Christians cannot bring up children of Jews and Saracens, and vice versa ${ }^{20}$.

The provision on schools was repeated by the twelfth ecumenical council (Fourth Council of the Lateran), but it was stressed that they should be established at "churches with sufficient resources". This one of the most important medieval councils was convened by Pope Innocent III. A total of 404 bishops participated in it and the total number

${ }^{15}$ KUMOR, B., Historia Kościoła, part 3: Zloty okres średniowiecza chrześcijańskiego, Lublin 1976, p. 31.

${ }^{16}$ Dokumenty soborów powszechnych, vol. 2, p. 171.

${ }^{17}$ Ibidem, p. 193. Canon XVIII: Ut prelati provideant magistris scholarum necessaria.

${ }^{18}$ Ibidem. See: KUMOR, B., Historia Kościoła, part 3, p. 97. Cf.: KNOWLES, M.D., OBOLENSKY, D., Historia Kościoła, vol. 2: 600-1500, Warsaw 1988, p. 170. It is worth noting that the term licentia docendi appeared a few years before the council in the letter of Alexander III, written in ca. 1170-1172 - Epistola et privilegia 87, [in:] Patrologiae cursus completus, ed. P. MIGNE, series latina, vol. 200, p. 741. The issue of such a licence was a legal basis for establishing first universities.

${ }^{19}$ Dokumenty soborów powszechnych, vol. 2, p. 193.

${ }^{20}$ Ibidem, p. 201. 
of all participants was estimated at 1,200 people. The Fourth Council of the Lateran held on 11-30 November 1215, enacted its decisions in 71 constitutions. The Council ordered in Canon XI that in the cathedral or collegiate chapters a benefice should be granted for a theologian who, as a theology teacher, should teach the clergy pastoral ministries and teach them sacra pagina and preach. The pedagogical role of these theologians is of utmost importance due to the fact that they were to prepare collections of sermons to be preached to a wide circle of the faithful ${ }^{21}$. The educational subjects of these sermons concerned, among other things, education for young people, especially girls, and included advice for spouses and those engaged. The method of educating future priests in the period of our interest was neither specifically regulated, especially in Poland, nor institutionalized $^{22}$. Prospective priests were educated in cathedral, parish or collegiate schools, while it was quite rare in the thirteenth century Poland to find priests who studied theology, for example, in Paris.

During the council, it was ordered, among other things, that provincial synods be annually convened with the task to implement the reforms ${ }^{23}$, preachers were appointed to assist the bishops in the "ministry of holy teaching ${ }^{24}$." Of particular interest are the provisions of the above-mentioned Constitution XI "On schoolmasters for the boys". It pointed out that many who wish to learn could not do it because of the lack of material resources and people who could teach ${ }^{25}$. In this situation, it was decided that schools should be created not only "in every cathedral church but also in other churches with sufficient resources". Teachers employed therein were "to teach grammar and other branches of study, as far as is possible, to the clerics of those and other churches", free of charge ${ }^{26}$. Let us note the clearly described corporate, ecclesiastical character of the schools. Cathedral schools were obliged to employ educated theologians to prepare candidates for priesthood. These teachers were financially privileged, as their remuneration was guaranteed by the archbishop, while the remaining were to be granted "adequate provision made for the grammarian in another church of the city or diocese" 27 . Thus, we can see that the church education was to be primarily provided to priests, whereas secular specialists were to be educated by universities, as the Constitution XVIII stated: “A cleric may not write or dictate letters which require punishments involving the shedding of blood, in the courts of princes this respon-

${ }^{21}$ See: BRACHA, K., Teolog - intelektualista i duszpasterz w społeczeństwie średniowiecznym, [in:] Kolory i struktury średniowiecza, ed. W. FAŁKOWSKI, Warsaw 2004, p. 136-154; Idem, Wokót tysogórskich kolekcji kazań z XV w. przypisywanych Piotrowi z Miłosławia. W kręgu małżeństwa i rodziny, [in:] Klasztor na Świętym Krzyżu w polskiej kulturze narodowej, ed. D. OLSZEWSKI and R. GRYZ, Kielce 2000.

22 In more detail: SKIERSKA, I., Pleban w późnośredniowiecznej Polsce, [in:] Kolory i struktury średniowiecza, p. 155-180.

${ }^{23}$ Dokumenty soborów powszechnych, vol. 2, p. 239.

${ }^{24}$ Ibidem, p. 247.

${ }^{25}$ Quia nonnulis propter inopiam et legendi studium et opportunitas proficiendi subtrahitur. Ibidem, p. 246.

${ }^{26}$ Ibidem, p. 247.

${ }^{27}$ Constitutions 11.3 and 11.4; Ibidem, p. 247-249. 
sibility should be entrusted to laymen and not to clerics" $" 28$. It meant that there were already enough lay people who could write and knew the art of preparing documents and educated in legal matters. The tendency to distinguish or specialize within the church education can be clearly seen in the wording of Constitution XXVII: "To guide souls is a supreme art. We therefore strictly order bishops carefully to prepare those who are to be promoted to the priesthood and to instruct them, either by themselves or through other suitable persons, in the divine services and the sacraments of the church, so that they may be able to celebrate them correctly" ${ }^{29}$. Therefore, a bishop was obliged personally to educate priests and examine candidates for their general education: nec literarum scientia suffragatur ${ }^{30}$. This order was recalled during the Second Council of Lyons in $1274^{31}$.

The last of general councils of our interest held in the twelfth through fourteenth centuries was the council convened to Vienne by Pope Clement V at the turn of 1311 and 1312, mainly for the deliberation of the question of the Templars. However, the Council decrees include also issues related to education. The Council's documents edited by Pope John XXII, include provisions regarding the teaching of the faithful by preachers from Dominican and Franciscan orders, competing in this respect with parish clergymen ${ }^{32}$. Moreover, the Pope drew attention to the need to explain to young monks the monastic rule by experienced masters ${ }^{33}$ and to hire appropriate teachers in monastery schools ${ }^{34}$.

Regarding the issue of the reception of church school legislation in medieval Poland, it should be emphasized that the Fourth Council of the Lateran was the first to host a large representation of the Polish episcopate, hence the conciliar provisions were introduced relatively quickly in Poland ${ }^{35}$. This can be seen in the school legislation of Polish provincial synods in the second half of the thirteenth century ${ }^{36}$. In order to raise the level of preach-

${ }^{28}$ Ibidem, p. 257.

${ }^{29}$ Ibidem, p. 267.

30 Ibidem, p. 271.

${ }^{31}$ Constitution II/13 [On the age of candidates for parsonage]; Ibidem, p. 433.

32 Council of Vienne, Decree 10. 5, [in:] Dokumenty soborów powszechnych, vol. 2, p. 551.

${ }^{33}$ Regula quoque cum in capitulo legitur, ab illo qui praest ipsi capitulo, vel alio cui hoc ipse iniunxerit, propter iuniores vulgaliter exponantur. Decree 14. 6; Ibidem, p. 560.

${ }^{34}$ Rursus ut ipsis monachis proficiendi in scientia via opportuna non desit, in singularis ipsorum monasteriis, quibus ad hoc supperunt facultates, idoneus teneatur magister, qui eos in primitivis scientiis instruat diligenter. Decree 14. 14; Ibidem, p. 566.

${ }^{35}$ Of course, this does not mean that the canon law was not known in Poland earlier. See: VETULANI, A., Z badań nad kultura prawnicza w Polsce piastowskiej, Wrocław 1976; TAUBENSCHLAG, R., Z badań nad znajomościa prawa kanonicznego w Polsce w XIII wieku, Warsaw 1949.

${ }^{36}$ For synods in medieval Poland, see: GROMNICKI, T., Synody prowincjonalne oraz czynności niektórych funkcjonariuszy apostolskich w Polsce do $r$. 1357, Kraków 1885; VETULANI, A., Historia źródet powszechnego prawa kanonicznego w zarysie, Kraków 1937; Idem, Statuty synodalne Henryka Kietlicza, Kraków 1938; ABRAHAM, W., Statuta synodu prowincjonalnego w Kaliszu z r. 1420, Kraków 1888; Idem, Studia i materiały do historii ustawodawstwa synodalnego w Polsce, Kraków 1915; HELCEL, A.Z., Ustawodawstwo Kościoła polskiego, [in:] Starodawne prawa polskiego pomniki, vol. 1, Kraków 1856, p. 333-342; UMIŃSKI, J., Henryk arcybiskup gnieźnieński zwany Kietliczem (1119-1219), Lublin 1926; ABRAHAM, W., Studia krytyczne do dzie- 
ing and teaching, the council obligated all bishops and archbishops that each time a priest theologian be at their respective cathedrals. Such a theologian should deal with the explanation of the Scriptures and pastoral work ${ }^{37}$.

One of significant effects of reforms in the Polish Church was the increase in the quality of the clergy's education. The first Polish scholastic that can be traced in the sources was Mateusz, the later Bishop of Krakow (1143). The first cathedral schools were probably those in Krakow, Gniezno and Poznań. The process of establishing cathedral schools in Poland was accelerated with the resolutions of the Third Council of the Lateran of 1179, which demanded that each cathedral church grant a benefice to maintain a master to provide teaching free of charge for the students ${ }^{38}$. Initially, these schools carried out a trivium programme after the preparatory stage, while the preferred subject was grammar and reading of selected authors. The elements of rhetoric and dialectics were cared for less. Quadrivium was not introduced until the 13th century In organisational terms, the cathedral school was subordinate to the bishop and the chapter, but practically it was supervised by a canon holding the title of scholastic. Teaching was the responsibility of the rector or master.

Organisational changes in the Polish education of the Middle Ages were related to the decisions of the Fourth Council of the Lateran of 1215: elementary schools were to be established in parishes, which should bear the burden of elementary teaching, while cathedral schools were to take care of educating future priests. The curriculum framework was relatively extensive. The school was to teach basic prayers and seven so-called penitential psalms, followed by the alphabet and reading. Church singing, the Latin grammar and reading of selected text in Latin were also taught. The pastoral ministry began to spread on a larger scale also as a result of the decision of the Council, which obliged the faithful to attend Sunday Mass, annual confession and to receive communion.

The reason for such a significant influence of the school legislation of the Fourth Council of the Lateran on the educational situation in the state ruled by the Piast dynasty was, beyond any doubt, the extensive participation of the Polish episcopate led by Archbishop Henryk Kietlicz ${ }^{39}$. Almost all the canons of this council were included in 1234 in the Decrees of Pope Gregory IX, which had the character of a church law code and, of

jów średniowiecznych synodów prowincjonalnych Kościoła polskiego, Kraków 1917; SAWICKI, J., Concilia Poloniae. Źródta i studia krytyczne, vol. 5: Synody archidiecezji gnieźnieńskiej i ich statuty, Warsaw 1950; Idem, Concilia Poloniae. Źródta i studia krytyczne, vol. 7, Synody diecezji poznańskiej i ich statuty, Poznań 1952; Statuta synodalia Andrae Episcopi Posnaniensis saeculo XV-mo confecta, ed. U. HEYZMANN, [in:] Starodawne prawa polskiego pomniki, vol. 5, Kraków 1878.

${ }^{37}$ More on the topic in: BRACHA, K., Teolog - intelektualista i duszpasterz w spoleczeństwie średniowiecznym, [in:] Kolory i struktury średniowiecza, p. 136-154.

38 Kultura Polski średniowiecznej, p. 295.

39 UMIŃSKI, J., Henryk arcybiskup gnieźnieński zwany Kietliczem; BARAN-KOZŁOWSKI, W., "Skład polskiej delegacji na obrady Soboru Laterańskiego IV”, Kwartalnik Historyczny, 2003, 110, p. 15 et seq.; Idem, Arcybiskup gnieźnieński Henryk Kietlicz (1199-1219). Działalność kościelna i polityczna, Poznań 2005, p. 204-213. 
course, were applicable in Poland ${ }^{40}$. On their basis, provincial synods were to introduce their resolutions into force ${ }^{41}$. The parish school in Krakow was founded by Bishop Iwo Odrowąż just a few years after the Council. In Wroclaw, such a school was established in 1267 at the church of Saint Mary Magdalene (which will be discussed further on); and in 1293 another one was established - at the church of Saint Elizabeth. In Poznań, however, even in 1263 the cathedral chapter still opposed the establishment of a school ${ }^{42}$.

The first synod, which concerned the Council's school legislation, was the synod held under the presidency of Jacques, Archdeacon of Leodium (Liège), on 10 October 1248, in Wrocław. The statutes of this synod are known via the bull of Urbano IV dated 3 July 1263. One of the postulates referred to the necessity of preaching in parishes to strengthen the Christian faith: presbyteris eruditi ad ecclesiam veniant festinanter were supposed to explain to the people the detailed Gospel message ${ }^{43}$. In addition, after the Credo and before the priest read the Gospel, the people would say in Polish the Lord's Prayer (Ojcze Nasz) and Apostles' Creed (Wierze w Boga). The Statutes of Łęczyca dated 1285 added to this the penitential act Confiteor, whose first words were "Kaję się Bogu" ("I confess to God") 44 . Both the basic prayers and penitential act, when repeated systematically, strengthened the knowledge of basic religious dogma. These texts were memorised by heart. The religious education of the faithful was to be completed by explaining to them the evangelical pericopes in Polish and preaching during the Mass.

Another important issue for the synod we were interested in was held in Łęczyca on October 14, 1257. Kronika Wielkopolska (The Chronicle of Wielkopolska) informs us about the date of the synod: anno quoque [eodem] at die beati Kalixti predictus dominus Fulco archiepiscopus Gneznensis Prandotha Cracoviensis, Thomas Wratislaviensis, Bogufalus Poznaniensis, Wolmirus Wladislaviensis, Andreas Plocensis, Wilhelmus Lubucensis episcopi ac multi abbates prelates et canonici ecclesiarum in Lancicia synodum celebrarunt ${ }^{45}$. The sessions of the synod were very fruitful, because: multe eciam constituciones in eadem sinodo fuerant ordinate. Que in ecclesis kathedralibus reservantur recondite $^{46}$. The Statutes approved by Archbishop of Gniezno Pełka governed the issues of church education as follows: Item statuimus, ut omnes ecclesiarum rectores seu plebani,

${ }^{40}$ SILNICKI, T., Sobory powszechne a Polska, Warsaw 1962, p. 40.

${ }^{41}$ The council recommended that provincial synods be held every year. This provision was not adhered to in Poland. See: DOWIAT, J., Historia Kościoła katolickiego w Polsce (do połowy XV wieku), Warsaw 1968, p. 139.

42 Kultura Polski średniowiecznej, p. 297.

43 Synodal statutes, [in:] Kodeks Dyplomatyczny Wielkopolski [hereinafter cited as: KDW], vol. 1, Poznań 1877, no. 274, p. 234.

${ }^{44}$ DOWIAT, J., op. cit., p. 155.

${ }^{45}$ Kronika Wielkopolska, ed. and introduction by B. KÜRBIS, [in:] Monumenta Poloniae Historica, series nova (hereinafter cited as $M P H$ ), vol. 8, Warsaw 1970, chapter 120, p. 109; Cf. texts of the statutes: $K D W$, vol. 1 , no. 361 , p. 321 et seq.

${ }^{46}$ Ibidem. See also: NOWACKI, J., “Arcybiskup gnieźnieński Janusz i nieznany synod prowincjonalny roku 1258”, Collactanea Theologica, 1933, 14, p. 159-165. 
vel qui cunque alii sint prelati per universam dyocesin Polonice gentis constituti, pro honore suarum ecclesiarum et laudem divinam, cum habeant scolas, per licenciam episcoporum statutas, non ponant Theutonicam gentem ad regendum ipsas, nisi sunt Polonica lingua, ad auctores exponendos pueros et Latinum Polonice, informati ${ }^{47}$. We see, therefore, that the preaching of sermons and teaching in schools were to be dealt with by Polishspeaking clergymen appointed by the church authorities. Teaching in Polish was to be provided for people who did not know Latin. Polish was used in schools only in the initial period of learning, before students learned Latin.

The most important postulates include the obligation to improve the quality of priests' education, popularization of parish education and the decision on religious teaching of the people in their national language, which has a decisive influence on the development of the literary Polish language. We have reasons to believe that one of responses to the postulate of the Synod of Łęczyca of 1257 was, among others, the establishment of a parish school in Poznań in 1263. The information on it is presented in Chapter 141 of Kronika Wielkopolska: 1263 fundata est ecclesia parochialis in civitate Poznaniensi nomine capituli Poznaniensi, sic quod dominicis diebus nec processionem neque scolas circa ipsam habere decebant. Sed omnes viri ecclesiastici tam civitas quam suburbani ad maioris ecclesie processionem et pueri scolas circa eandem consitutas fraquentare deberent ${ }^{48}$.

In 1267 another synod took place, presided over by Cardinal Guido, a legate appointed by Pope Clement $\mathrm{IV}^{49}$. Immediately after the conclusion of the synod, Cardinal Guido confirmed the creation of a school in Wrocław, at the church of St. Magdalene. It is worth quoting excerpts from this document, as they perfectly reflect the climate of civilisational changes that took place in the thirteenth-century Poland, which influenced the attitude to education. We can see that the school was created because there were many candidates from outside the city walls of Wrocław who wanted to learn and who were previously deprived of the opportunity to learn ${ }^{50}$. The document also contained a curriculum, perfectly corresponding to the relevant Conciliar provisions ${ }^{51}$. This issue was also discussed at the Synod of Buda, held in 1279 and presided by the Pope's legate Philip of Fermo, which

47 Statutes for the Polish church approved in Lęczyca on 14 October 1257. From the transumpt approved by Archbishop Jarosław on 10 January 1357; KDW, vol. 1, no. 361, p. 322.

${ }^{48}$ Kronika Wielkopolska, p. 117.

49 See: SILNICKI, T., Kardynat legat Gwido. Jego synod wrocławski w r. 1267 i statuty tego synodu [in:] Idem, Z dziejów Kościoła w Polsce, Warsaw 1960, p. 321-380. Text of the statutes also in: Schlesisches Urkundenbuch, Bd. IV: 1267-1281, ed. W. IRGANG, Köln-Wien 1988, no. 5, p. 4-9.

${ }^{50}$ Schlesisches Urkundenbuch, Bd. IV, op. cit., no. 7, Wrocław 12 February 1267, p. 10: "Sane in nostra proposuistis presentia constituti, quod pueri vestr et maxime parvuh frequentates scolas extra muros civitas Vratislaviensis, dum ad easdem scolas accedunt, tum propter locorum distantiam ac passus et accessus difficiles, qui sunt in pontibus strictis et fractis super flumina, tum etiam propter multitudinem hominum - - Quare nobis humiliter supplicastis, ut vobis et pueris vestris parvulis in posterum providere et contra predicta incommoda salubre remedium adhibere paterna sollicitudine dignaremur.” The original wording has been kept.

${ }^{51}$ Ibidem, p. 11: “- - in quibus [i.e. in the Mary Magdalene School - K. R.] pueri parvuli doceantur et discant alphabetum cum oratione dominica et salutationem beate Marie Virginis cum symbolo, psalterio et septem psalmis, discant etiam ibidem cantum, ut in ecclessis ad honorem dei legere valeant et cantare, audiant etiam in eisdem scolis Donatum, Cathonem et Theodolum ac regulas pueriles." The best students were later to be sent to 
proclaimed, among other things, subjects of parish teaching for the Church in Hungary and Poland. It was instructed that the faithful be explained the truths of faith in their own language ${ }^{52}$. This Synod is linked with the Synod of Wrocław of 25 June 1279, which impose on priests the obligation to explain the Gospel readings in the language of vulgari, i.e. the native language of the faithful, publice in ecclesia recitent post evangelium, in vulgari fideliter et diligenter exponant ${ }^{53}$.

The school statutes of the Synod of Łęczyca of 1285 resulted from the socio-economic development of Poland in the second half of the 13th century. At that time, the expansion of German as a language of the royal court, the Church and school even threatened the monopoly of Latin in public life. The pontificate of Archbishop Jakub Świnka (12831314) was filled with struggle for Polish language. At the synod of Łęczyca of 6 January 1285 , the clergy were recommended to pray with the people in Polish and to give sermons in that language as much as possible ${ }^{54}$. It was also instructed to use Polish, and not German, in elementary education before students learn Latin: [...] ponatur rectores scolarium, nisi linguam Polonicam proprie sciant, et possint pueris auctores exponere in Polonica lingua ${ }^{55}$; therefore it was forbidden to appoint people who do not speak the local language as rectors of parish schools ${ }^{56}$. Candidates for vicars had to undergo an examination to test their command of the Polish language ${ }^{57}$. Archbishop Jakub Świnka appealed to the scholarly clerics (peniti) having expertise in the interpretation of the Holy Scriptures that they explain Sunday's Gospel during the Mass ${ }^{58}$. To improve the organization of life in parishes, the obligation to register births and deaths in parish registers was introduced.

the Wrocław cathedral school to continue their education. Later on, the school was granted an additional legal protection, see: Ibidem, no. 8, p. 11; no. 12 , p. 13.

52 SKRZYNIARZ, R., Nauczanie średniowiecznego Kościoła polskiego w świetle kazań świętokrzyskich i kazań gnieźnieńskich, [in:] Średniowieczny Kościót polski. Z dziejów duszpasterstwa i organizacji kościelnej, ed. M.T. ZAHAJKIEWICZ, S. TYLUS SAC, Lublin 1999, p. 94.

53 Schlesisches Urkundenbuch, Bd. IV, op. cit., no. 362, p. 240.

54 The date of the synod is known from: Rocznik Traski, [in:] MPH, vol. 2, p. 850; See also: KDW, vol. 1, no. 616; STENZEL, W., Urkunden zur Geschichte des Bisthums Breslau im Mittelalter, no. 136; no. 137; no. $151 ;$ no.169.

55 Synodal statutes of Archbishop Jakub ŚWINKA, $K D W$, vol. 1, no. 551, p. 511. These statutes were later confirmed on 8-10 January 1357 by Archbishop Jarosław, publ.: KDW, vol. 3, Poznań 1879, no. 1349-1350, p. 59 et seq. See also: Constitutiones Jacobi Archiepiscopi Gnesnensis anno 1285 in Lanciciensi synodo editae, publ. A. Z. HELCEL, [in:] Starodawne prawa polskiego pomniki, vol. 1, Warsaw 1856, p. 383-384.

${ }^{56}$ Kultura Polski średniowiecznej X-XIII w., ed. J. DOWIAT, Warsaw 1985, p. 207. See also: TASZYCKI, W., Obrońcy języka polskiego, Wrocław 1953; MAYENOWA, M. R., Walka o język w życiu i literaturze staropolskiej, Warsaw 1955; ABRAHAM, W., Studia krytyczne do dziejów średniowiecznych synodów, p. 51.

57 DOWIAT, J., Historia Kościoła katolickiego w Polsce, p. 144.

${ }^{58}$ See: WOLNY, J., Kaznodziejstwo, [in:] Dzieje teologii katolickiej w Polsce, vol. 1, Średniowiecze, ed. M. RECHOWICZ, Lublin 1974, p. 294-296; Idem, "Materiały do nauczania wiary w Polsce średniowiecznej”, Analecta Cracoviensia, 1995, R. 27, p. 653-659. 
It was also decided that all parishes should possess a hagiography of Saint Adalbert for didactic purposes. This book was to be used and read out to the faithful ${ }^{59}$.

At the Synod of Łęczyca of 16 October 1287, a decision was made about teachers in parish schools, already numerous in cities and larger villages at the end of the 13 th century. It was an extension of Chapter 6 of the statutes of the previous assembly of bishops referring to cathedral and conventual schools ${ }^{60}$.

First attempts to implement synodal provisions regarding sermons in Polish were made at the end of the thirteenth century. In this period originates the first version of the so-called Kazania świętokrzyskie (Holy Cross Sermons), known from a manuscript dating from the fourteenth century ${ }^{61}$. They were probably created in the clerical milieu of Krakow and were intended for the local clergy ${ }^{62}$. At the end of the thirteenth century, a Latin collection of Sunday sermons (de tempore) and sermons about saints (de sanctis) was written by a Dominican friar, Peregrine of Opole ${ }^{63}$. The topics in the sermons were illustrated by sensual and material images. At the turn of the fourteenth and fifteenth centuries, Kazania gnieźnieńskie (Gniezno Sermons) were written, probably by Łukasz of Wielki Koźmin (ca. 1370 - ca. 1412), presenting a popular trend of ecclesiastical pronunciation adapted to intellectual capabilities and spiritual needs of uneducated listeners ${ }^{64}$.

Intensification of the concern of spiritual authorities for the proper teaching of the faithful is clearly visible in the rapid development of the parish network in Poland in the 13th century as a result of implementing the decisions of the Fourth Council of the Lateran. While it is estimated that at the end of the 12th century there were no more than 800-1000 parishes in the Polish territory, in the early 14th century their number fluctuated within $2000^{65}$. Catechesis should be given in vulgari, i.e. in the local language. The increase in the number of parishes, at least theoretically, resulted in the number of parish schools, and thus the availability of school education.

59 Synodal statutes of Archbishop Jakub ŚWINKA, $K D W$, vol. 1, no. 551, p. 511.

${ }^{60}$ Starodawne prawa polskiego pomniki, vol. 1, no. 17, p. 338; p. 414; See also ABRAHAM, W., Studia krytyczne, p. 51; KĘTRZYŃSKI, S., Synod tęczycki 1287 r., [in:] Sprawozdanie Narodowego Zaktadu im. Ossolińskich we Lwowie, 1888, p. 92.

${ }^{61}$ Kultura Polski średniowiecznej, p. 208.

${ }^{62}$ See the text in: Kazania tzw. świętokrzyskie, publ. and ed. J. ŁOŚ, W. SEMKOWICZ, Kraków 1934. More on the topic in: SKRZYNIARZ, R., Nauczanie średniowiecznego Kościoła, p. 94 et seq.

${ }^{63}$ See: WOLNY, J., Przekłady tacińskich kazań Peregryna z Opola, [in:] Benedyktyńska praca. Studia historyczne ofiarowane O. Pawłowi Sczanieckiemu w 80 rocznice urodzin, ed. o. J.A. SPIEŻ OP, Z. WIELGOSZ, Kraków 1997, p. 141-148. See also: Idem, Laciński zbiór kazań Peregryna z Opola i ich zwiąek z tzw. “Kazaniami gnieźnieńskimi”, [in:] Średniowiecze. Studia o kulturze, Warsaw 1961, p. 171-238.

${ }^{64}$ See: SRZYNIARZ, R., Nauczanie średniowiecznego Kościoła, p. 95 et seq. Edition: Kazania gnieźnieńskie, [in:] Chrestomatia staropolska. Teksty do roku 1543, publ. W. WYRWA, W.R. RZEPKA, Wrocław 1984, p. 96-104.

${ }^{65}$ Cf.: WIŚNIOWSKI, E., Rozwój organizacji parafialnej w Polsce do czasów reformacji, [in:] Kościót w Polsce, vol. 1: Średniowiecze, ed. J. KŁOCZOWSKI, Kraków 1966; SILNICKI, T., Z dziejów Kościoła w Polsce, Warsaw 1960; TAZBIROWA, J., "Początki organizacji parafialnej w Polsce", Przegląd Historyczny, 1963, R. 54, vol. 3. 
In the thirteenth century, monasteries were also more and more eager to open their schools for lay people. It is difficult to point out a direct link with the relevant provisions of Conciliar laws, nevertheless, this indicates a general tendency of growing interest in acquiring education. We must remember that monks of this period were the best educated group of clergy. In 1248, teaching of the texts of basic prayers in Polish was introduced into the teaching practice of all church schools, which was thereafter confirmed in the statute of Archbishop Jakub Świnka of $1285^{66}$. According to the statute, the command of Polish was an important criterion in appointing the teachers ${ }^{67}$. As far as monastic education is concerned, it should be first noted that its organization or the very existence thereof depended strictly on the spirituality of the given congregation, its priorities, the level of contact with the world of profanum and many other factors. For the Augustians, according to the constitutions of the Order, youth education was one of the basic tasks of convents. The curriculum included ars scribendi, ars dictandi, singing and seven liberal arts. The Wrocław school of Augustians from the beginning of its existence was open not only to the novices of this order ${ }^{68}$. Also the Dominicans applied strictly to the role of educators entrusted to them, although they did so on two levels. Their schools kept the statute of schola interna, preparing preachers who then taught in churches ${ }^{69}$. At first, the Cistercians did not pay much attention to educational issues, but they changed their attitude in the twenties of the 13th century under the influence of an Oxford University graduate, Abbot of Citeaux Stephen Lexington, founder of the Cistercian college in Paris in $1245^{70}$.

The analysis presented is a preliminary outline of the question that needs further research, but it has shown a significant role of church school legislation in the development of education in medieval Poland. It can also be noticed that all changes in this matter resulted from both the legislative activity of the Church and the response to the educational needs of the society. The latter resulted from the general civilisational development of Latin Europe, part of which formed the lands under the rule of the Piast Dynasty.

${ }^{66}$ Schlesisches Urkundenbuch, Bd. II, ed. W. IRGANG, Wien-Köln 1978, no. 346, p. 213: "De oratione dominica et symbolo exponendo. Denique vobis iniungimus, ut in vestris synodis presbyteris iniungatis, quatinus singulis diebus dominicis et festivis post euvangelium dicant publice in vulgari suo orationem dominicam et symbolum vel ad minus orationem dominicam in latino et symbolum in vulgari."

${ }^{67} K D W$, vol. 1 , no. 551 .

${ }^{68}$ See: BOBOWSKI, K., Szkoty klasztorne w średniowiecznym Wrocławiu, [in:] Kultura edukacyjna na Górnym Śląsku, ed. A. BARCIAK, Wrocław 2002, p. 23; KACZMAREK, K., "Dla dobra konwentu i świeckich. Szkoły w norbertańskim opactwie św. Wincentego we Wrocławiu w okresie średniowiecza”, Nasza Przeszłość, 1998,89 , p. 87 et seq.

${ }^{69}$ KIELAR, P., “Organizacja szkolnictwa dominikańskiego w Polsce w XIV w.”, Studia Philosophiae Christianae, 1969,1, p. 315 et seq.

${ }^{70}$ More on the topic in: KACZMAREK, K., Studia uniwersyteckie cystersów z ziem polskich $w$ okresie średniowiecza, Poznań 2002 and other works of this author. 


\title{
Bibliography
}

\author{
I. Sources
}

ABRAHAM, W., Statuta synodu prowincjonalnego w Kaliszu z r. 1420, Kraków 1888.

Admonitio generalis, ed. A. BORETIUS, [in:] Monumenta Germaniae Historica, Capitularia rerum Francorum, vol 1, ed. G.H. PERTZ, Berlin 1835.

Constitutiones Jacobi Archiepiscopi Gnesnensis anno 1285 in Lanciciensi synodo editae, publ. A.Z. HELCEL, [in:] Starodawne prawa polskiego pomniki, vol. 1, Warszawa 1856.

Dokumenty soborów powszechnych, vol. 1: Nicea I, Konstantynopol I, Efez, Chalcedon, Konstantynopol II, Konstantynopol III, Nicea II, ed. A. BARON, H. PIETRAS SJ, Kraków 2001

Dokumenty soborów powszechnych, vol. 2: (869-1312) Konstantynopol IV, Lateran I, Lateran II, Lateran III, Lateran IV, Lyon I, Lyon II, Vienne, ed. A. BARON, H. PIETRAS SJ, Kraków 2002.

Epistola et privilegia, [in:] Patrologiae cursus completus, ed. P. MIGNE, series: Latina, vol. 200, Paris 1879.

HELCEL, A.Z., Ustawodawstwo Kościoła polskiego, [in:] Starodawne prawa polskiego pomniki, vol. 1, Kraków 1856.

Kazania gnieźnieńskie, [in:] Chrestomatia staropolska. Teksty do roku 1543, publ. W. WYRWA, W.R. RZEPKA, Wrocław 1984.

Kazania tzw. świętokrzyskie, publ. and ed. J. ŁOŚ, W. SEMKOWICZ, Kraków 1934.

Kodeks dyplomatyczny Wielkopolski, vol. 1, Poznań 1877.

Kronika Wielkopolska, ed. B. KÜRBIS, [in:] Monumenta Poloniae Historica, series nova, vol. 8, Warszawa 1970.

Monumenta Germaniae Historica, legum sectio III: Concilia, vol. 2: Concilia aevi Karolini I, pars 1, part 2, ed. A. WERMINGHOFF, Hannover-Leipzig 1908.

Monumenta Germaniae Historica, legum sectio III: Concilia, vol. 2: Concilia aevi Karolini I, pars 1, ed. A. WERMINGHOFF, Hannover-Leipzig 1906.

SAWICKI, J., Concilia Poloniae. Źródła i studia krytyczne, vol. 5: Synody archidiecezji gnieźnieńskiej i ich statuty, Warszawa 1950.

SAWICKI, J., Concilia Poloniae. Źródła i studia krytyczne, vol. 7: Synody diecezji poznańskiej i ich statuty, Poznań 1952.

Schlesisches Urkundenbuch, Bd. 2, ed. W. IRGANG, Wien-Köln 1978.

Statuta synodalia Andrae Episcopi Posnaniensis saeculo XV-mo confecta, ed. U. HEYZMANN, [in:] Starodawne prawa polskiego pomniki, vol. 5, Kraków 1878.

Synody i kolekcje praw, vol. 1: Dokumenty synodów od 50 do 381 roku, ed. A. BARON, H. PIETRAS SJ, Kraków 2006

\section{Studies}

ABRAHAM, W., Studia i materiaty do historii ustawodawstwa synodalnego w Polsce, Kraków 1915.

ABRAHAM, W., Studia krytyczne do dziejów średniowiecznych synodów prowincjonalnych Kościoła polskiego, Kraków 1917

BARAN-KOZŁOWSKI, W., „Skład polskiej delegacji na obrady Soboru Laterańskiego IV”, Kwartalnik Historyczny, 2003, 110.

BARAN-KOZŁOWSKI, W., Arcybiskup gnieźnieński Henryk Kietlicz (1199-1219). Działalność kościelna i polityczna, Poznań 2005. 
BOBOWSKI, K., Szkoły klasztorne w średniowiecznym Wrocławiu, [in:] Kultura edukacyjna na Górnym Ślasku, ed. A. BARCIAK, Wrocław 2002

BRACHA, K., Teolog - intelektualista i duszpasterz w spoleczeństwie średniowiecznym, [in:] Kolory i struktury średniowiecza, ed. W. FAŁKOWSKI, Warszawa 2004.

BRACHA, K., Wokół tysogórskich kolekcji kazań z XV w. przypisywanych Piotrowi z Miłosławia. W kręgu matzeństwa i rodziny, [in:] Klasztor na Świętym Krzyżu w polskiej kulturze narodowej, ed. D. OLSZEWSKI, R. GRYZ, Kielce 2000.

DOWIAT, J., Historia Kościoła katolickiego w Polsce (do połowy XV wieku), Warszawa 1968.

FAŁKOWSKI, W., Admonitio generalis Karola Wielkiego - zapowiedź tworzenia państwa idealnego, [in:] Ludzie, Kościól, wierzenia. Studia z dziejów kultury i społeczeństwa Europy Środkowej (średniowiecze - wczesna epoka nowożytna), ed. W. IWAŃCZAK, S.K. KUCZYŃSKI, Warszawa 2001.

GROMNICKI, T., Synody prowincjonalne oraz czynności niektórych funkcjonariuszy apostolskich $w$ Polsce do r. 1357, Kraków 1885.

KACZMAREK, K., „Dla dobra konwentu i świeckich. Szkoły w norbertańskim opactwie św. Wincentego we Wrocławiu w okresie średniowiecza", Nasza Przeszłość, 1998, 89.

KACZMAREK, K., Studia uniwersyteckie cystersów z ziem polskich w okresie średniowiecza, Poznań 2002.

KĘTRZYŃSKI, W., Synod tęczycki 1287 r., [in:] Sprawozdanie Narodowego Zakładu im. Ossolińskich we Lwowie, Lwów 1888.

KIELAR, P., „Organizacja szkolnictwa dominikańskiego w Polsce w XIV w.”, Studia Philosophiae Christianae, 1969, 1.

KNOWLES, M.D., OBOLENSKY, D., Historia Kościoła, vol. 2: 600-1500, Warszawa 1988

Kultura Polski średniowiecznej X-XIII w., ed. J. DOWIAT, Warszawa 1985.

KUMOR, B., Historia Kościoła, part 3: Złoty okres średniowiecza chrześcijańskiego, Lublin 1976.

MAYENOWA, M.R., Walka o język w życiu i literaturze staropolskiej, Warszawa 1955.

MINNERATH, R., Sobory, Warszawa 2004.

NOWACKI, J., „Arcybiskup gnieźnieński Janusz i nieznany synod prowincjonalny roku 1258”, Collactanea Theologica, 1933, 14.

RICHÉ, P., Edukacja i kultura w Europie Zachodniej (VI-VIII w.), Warszawa 1995.

SEREJSKI, M., Karol Wielki na tle swoich czasów, Warszawa 1959.

SILNICKI, T., Sobory powszechne a Polska, Warszawa 1962.

SILNICKI, T., Z dziejów Kościoła w Polsce, Warszawa 1960.

SKIERSKA, I., Pleban w późnośredniowiecznej Polsce, [in:] Kolory i struktury średniowiecza, ed. W. FAŁKOWSKI, Warszawa 2004.

SKRZYNIARZ, R., Nauczanie średniowiecznego Kościoła polskiego wświetle kazań świętokrzyskich i kazań gnieźnieńskich, [in:] Średniowieczny Kościót polski. Z dziejów duszpasterstwa i organizacji kościelnej, ed. M.T. ZAHAJKIEWICZ, S. TYLUS SAC, Lublin 1999.

TASZYCKI, W., Obrońcy języka polskiego, Wrocław 1953.

TAUBENSCHLAG, R., Z badań nad znajomościa prawa kanonicznego w Polsce XIII wieku, Warszawa 1949.

TAZBIROWA, J., „Początki organizacji parafialnej w Polsce”, Przegląd Historyczny, 1963, 54, vol. 3.

UMIŃSKI, J., Henryk arcybiskup gnieźnieński zwany Kietliczem (1199-1219), Lublin 1926.

VETULANI, A., Historia źródeł powszechnego prawa kanonicznego w zarysie, Kraków 1937.

VETULANI, A., Statuty synodalne Henryka Kietlicza, Kraków 1938.

VETULANI, A., Z badań nad kultura prawnicza w Polsce piastowskiej, Wrocław 1976.

WIŚNIOWSKI, E., Rozwój organizacji parafialnej w Polsce do czasów reformacji, [in:] Kościót w Polsce, vol. 1: Średniowiecze, ed. J. KŁOCZOWSKI, Kraków 1966. 
WOLNY, J., „Materiały do nauczania wiary w Polsce średniowiecznej”, Analecta Cracoviensia, 1995, 27.

WOLNY, J., Kaznodziejstwo, [in:] Dzieje teologii katolickiej w Polsce, vol. 1: Średniowiecze, ed. M. RECHOWICZ, Lublin 1974.

WOLNY, J., Łaciński przekład kazań Peregryna z Opola $i$ ich zwiazek z tzw. „Kazaniami gnieźnieńskimi”, [in:] Średniowiecze. Studia o kulturze, Warszawa 1961.

WOLNY, J., Przektady łacińskich kazań Peregryna z Opola, [in:] Benedyktyńska praca. Studia historyczne ofiarowane O. Pawtowi Sczanieckiemu w 80 rocznicę urodzin, ed. J.A. SPIEŻ OP, Z. WIELGOSZ, Kraków 1997.

Originally published in "Biuletyn Historii Wychowania", 2007, vol. 23, pp. 7-19 